\title{
Editorial: The International Journal of Latin American Religions-a Response to the Academic Demands of a Dynamic Field of Research
}

\author{
Frank Usarski ${ }^{1}$
}

Published online: 8 May 2017

(C) Springer International Publishing AG 2017

The dynamics of globalization, the increasing interconnectedness due to modern communications technology, and the growing importance of academic transnational networking have significant consequences for the study of religion. Flows of migration, international missionary activities, and the "import" of previously distant spiritual ideas and methods have contributed to the ongoing diversification of domestic religious landscapes. Easy accessibility to information about religious phenomena at virtually any place of the Earth have sharpened the researchers' awareness both for the complexity of their field of study and for the worldwide academic conquests and desiderata in their realm of expertise.

Under these circumstances, one could observe in the last two decades a growing interest in the intellectual outcome of collective efforts of Latin American researchers dedicated to the study of religions of their countries. (Torre and Martín 2016) Simultaneously, there has been an intensification of academic activities on an international level concerning religious phenomena specific to Latin America. One indicator of the latter is the supply of a new publication-market niche through series like "Religion in the Americas" and "Jewish Latin America" launched by Brill in 2002 and 2011, respectively. Also symptomatic is the fact that some important reference works have become available, among them Springer's Encyclopedia of Latin American Religions (Gooren 2016) and the Cambridge History of Religions in Latin America (Garrard-Burnett et al. 2016). The same is true for recently published general overviews (Garrard-Burnett 2000; Chesnut 2003; González and González 2008; Peterson and Vasquez 2008; Penyak and Petri, 2009; Lynch 2012; Vaggione and Faúndes 2017) and insights into the dynamics of Latin America's religious field (Steigenga and Cleary 2007; Patterson 2014). This trend has also favored the study of dominant and sociohistorically well-established traditions. Alongside surveys of Latin American

Frank Usarski

usarski@pucsp.br; usarski@ymail.com

1 Pontifícia Universidade Católica de São Paulo, São Paulo, Brazil 
Christianity (Hartch 2014), one finds more specific studies on Catholicism (Cleary 2009; Schwaller 2011; Prien 2012; Levine 2014) and on manifestations of "popular religion" (Greer and Bilinkoff 2002; Graziano 2006; Saulsbury 2008). Other issues continuously popular among researchers of Latin American religions are Mesoamerican Religions (Sullivan 2002; Staller and Stross 2013), the religions of Indigenous Peoples (Cleary and Steigenga 2004), Afro-Latin Religions (Murrell 2010; Olmos and Parvisini-Gebert 2011), and Protestantism (Mulder et al. 2017), especially Pentecostalism (Corten and Marshall-Fratani 2001; Freston 2008; Smith 2011; Lindhardt 2016). Simultaneously, less studied or even neglected currents such as the New Age Movement (Torre et al. 2016), Islam (Khan 2015; Logroño Narbona et al., 2016), and-already mentioned-Judaism (Lesser and Rein 2008; Ran and Cahan 2012) have begun to draw attention of the international scientific community dedicated to the study of Latin American religions.

Moreover, since religious phenomena previously restricted to Latin America have gained a worldwide relevance, the spectrum of literature on related matters is expanding. Recently published books show an interest in religious experiences and practices of Latin American immigrants - for example, in the USA (Avalos 2004; Matovina 2012), or in Japan (Quero and Shoji 2014). Other publications deal with the translocation (Rocha and Vásquez 2013) and internationalization of Latin American Religions such as Ayahuasca Rituals (Rios and Rumrill, 2008; Labate and Jungaberle 2011; Labate et al. 2016), Afro-Latin religions (Torre 2004; Schmidt 2008) or Pentecostalism among ethnic groups of Latin American provenience outside Latin America (Sánchez-Walsh 2003; Espinosa 2014; Medina and Alfaro 2015).

With this inaugural issue, the International Journal of Latin American Religions is setting about to contribute to the progress of the academic activities summarized above. The periodical aims to promote the non-theological, multidisciplinary research both of religious phenomena in Latin America and among Latin American minorities in different parts of the world. Needless to say, that with this orientation, the International Journal of Latin American Religions is far from standing alone. On the contrary, the editors recognize the importance of scientific societies such as the Asociación Latinoamericana para el Estudio de las Religiones, the Asociación de Cientistas Sociales de la Religión del Mercosur, the Associação Brasileira de História das Religiões, or the Sociedad Mexicana para el Estudio de las Religiones. We also pay respect to the precious intellectual work of more specific institutions such as the Latin American Jewish Studies Association or to specialized working groups within thematically more comprehensive academic organizations interested in Religion and/or in Latin America in general. In the same spirit, we understand our new periodical as a medium that is complementary to already existing periodicals, whether they are limited to religious issues related to Latin America (Religião e Sociedade, Revista Ciencias Sociales y Religión, Revista Académica para el Estudio de las Religiones, among others) or open for the inclusion of related studies (such as The Canadian Journal of Latin American and Caribbean Studies; the Latin American Research Review, the Hispanic American Historical Review or the Journal of Latin American Studies).

Within this wider horizon, the International Journal of Latin American Religions offers a space for the integration of the results of non-theological studies of the relevant field, regardless of the national and institutional contexts in which they were obtained. 
Our periodical invites interested scholars to contribute to the journal through articles, reports and book reviews. One can expect that these efforts will not be only intellectual profitable for colleagues directly engaged in the research of Latin American religions. Rather, there are hopefully many students of religion of other areas of expertise, who will welcome the International Journal of Latin American Religions as an opportunity to obtain knowledge of a rich, diverse, and highly dynamic field of research, which under the condition of an increasingly globalized world demands adequate academic attention.

\section{References}

Avalos, H (2004) Introduction to the U.S. Latina and Latino Religious Experience. Brill, Leiden/Boston Chesnut RA (2003) Competitive spirits: Latin America's new religious economy. Oxford University Press, New York

Cleary EL (2009) How Latin America saved the soul of the Catholic Church. Paulist Press, New York and Mahway

Cleary EL, Steigenga TJ (2004) Resurgent voices in Latin America: indigenous peoples, political mobilization, and religious change. Rutgers University Press, New Brunswick

Corten A, Marshall-Fratani R (2001) Between Babel and Pentecost: transnational Pentecostalism in Africa and Latin America. Indiana University Press, Bloomington

Espinosa GL (2014) Pentecostals in America, faith and politics in action. Harvard University Press, Cambridge

Freston P (ed) (2008) Evangelical Christianity and democracy in Latin America. Oxford University Press, New York

Garrard-Burnett V (2000) On Earth as it is in Heaven: Religion in Modern Latin America. Scholarly Resources Wilmington, DE

Garrard-Burnett V, Freston P, Dove SC (eds) (2016) The Cambridge History of Religions in Latin America. Cambridge University Press, New York

González JL, González OE (2008) Christianity in Latin America: a History. Cambridge University Press, New York

Gooren H (ed) (2016) Encyclopedia of Latin American religions. Springer International Publishing, Cham

Graziano F (2006) Cultures of devotion: folk saints of Spanish America. Oxford University Press, New York

Greer A, Bilinkoff J (eds) (2002) Colonial saints: discovering the holy in the Americas, 1500-1800. Routledge, New York

Hartch T (2014) The rebirth of Latin American Christianity. Oxford University Press, New York

Khan A (ed) (2015) Islam and the Americas. University Press of Florida, Gainsville

Labate BC, Cavnar C, Alex K, Gearin AK (2016) The World Ayahuasca. Diaspora, Reinventions and Controversies. Routledge, New York

Labate BC, Jungaberle H (eds) (2011) The internationalization of Ayahuasca. LIT Verlag, Münster

Lesser J, Rein R (eds) (2008) Rethinking Jewish-Latin Americans. University of New Mexico Press, Albuquerque

Levine DH (2014) Popular voices in Latin American Catholicism. Princeton University Press, Princeton

Lindhardt M (ed) (2016) New ways of being Pentecostal in Latin America. Lexington Books, Lanham

Logroño Narbona MM, Hilu PG, Pinto R, Karam JT (2016) Crescent over another horizon: Islam in Latin America, the Caribbean, and Latino USA. University of Texas Press, Austin/TX

Lynch J (2012) New worlds: a religious history of Latin America. Yale University Press, New Haven

Matovina T (2012) Latino Catholicism: Transformation in America's Largest Church Princeton and Oxford: Princeton University Press

Medina N, Alfaro S (eds) (2015) Pentecostals and charismatics in Latin America and Latino communities. Palgrave Macmillan, New York

Mulder M, Ramos AI, Marti G (2017) Latino Protestants in America. Rowman \& Littlefield, Lanham

Murrell NS (2010) Afro-Caribbean Religions. An Introduction to their Historical, Cultural, and Sacred Traditions. Temple University Press 
Olmos MF, Parvisini-Gebert L (2011) Creole religions of the Caribbean: an Introduction from Vodou and Santeria to Obeah and Espiritismo. New York University Press, New York

Patterson E (2014) Latin America's neo-reformation: religion's influence on contemporary politics. Routledge, New York

Penyak LM, Petri WJ (eds) (2009) Religion and Society in Latin America: interpretive essays from conquest to present, Orbis books. Maryknoll, New York

Peterson AL, Vasquez MA (eds) (2008) Latin American religions: histories and documents. New York University Press, New York

Prien HJ (2012) Christianity in Latin America. Brill, Leiden and Boston

Quero HC, Shoji R (eds) (2014) Translational faiths: Latin-American Immigrants and their Religions in Japan. Ashgate, Farnham

Ran A, Cahan JA, eds. (2012) Returning to Babel. Jewish Latin American Experiences, Representations, and Identity. Brill, Leiden and Boston

Rios MD, Rumrill R:(2008) A Hallucinogenic Tea, Laced with Controversy. Ayahuasca in the Amazon and the United States. Praeger, Westport, Connecticut, and London

Rocha C, Vásquez M (eds) (2013) The Diaspora of Brazilian religions. Brill, Leiden and Boston

Sánchez-Walsh AM (2003) (2003) Latino Pentecostal identity: evangelical Faith, self, and society. Columbia University Press, New York

Saulsbury AK (2008) The issue of power and local saints in Latin America. University of Texas at San Antonio, San Antonio

Schmidt B (2008) Caribbean Diaspora in the USA: Diversity of Religions in New York City. Ashgate Farnham

Schwaller JF (2011) The History of the Catholic Church in Latin America. From conquest to revolution and beyond. New York University Press, New York and London

Smith C (ed) (2011) Pentecostal power: expressions, impact and Faith of Latin American Pentecostalism. Brill, Leiden

Staller JE, Stross B (2013) Lightning in the Andes and Mesoamerica. Oxford University Press, New York

Steigenga TJ, Cleary EL (2007) Conversion of a Continent. Contemporary Religious Change in Latin America. Rutgers University Press, New Brunswick

Sullivan LE (2002) Native religions and cultures of central and South America. Continuum, New York

Torre MA (2004) Santeria: the beliefs and rituals of a growing religion in America. Eerdmans, Grand Rapids and Cambridge

Torre R, Zúñiga CG, Huet NJ (eds) (2016) New age in Latin America. Popular Variations and Ethnic Appropriations. Brill, Leiden and Boston

Torre R, Martín E (2016) Religious studies in Latin America. Annu Rev Sociol 42:473-492. doi:10.1146 /annurev-soc-081715-074427

Vaggione JM, Faúndes JMM (eds) (2017) Boundaries of religious freedom: regulating religion in diverse societies, Springer international publishing, Cham 